\title{
Caracterization of seed germination of Zephyranthes sylvatica (Mart.) Baker (Amarilidacea) ${ }^{1}$
}

\author{
Mayara Wesley da Silva², Laise Guerra Barbosa², José Eduardo Santos Barboza \\ da Silva ${ }^{2}$, Keylan Silva Guirra ${ }^{2}$, Diego Rangel da Silva Gama², \\ Gilmara Moreira de Oliveira², Bárbara França Dantas ${ }^{3^{*}}$
}

\begin{abstract}
Zephyranthes sylvatica is a beautiful lily, endemic from the Brazilian Caatinga. Although it has a great ornamental potential, little is known about this species, especially regarding its seeds germination process. Aiming to characterize the germination of $Z$. sylvatica seeds, we studied its imbibition curve, optimum temperature and substrate for germination and seedling emergence, osmotic and salt stress tolerance, as well as the tolerance to frosting/ defrosting, which indicates long term cryostorage potential. The germination of $Z$. sylvatica presents a triphasic model of imbibition, in which the primary root protrusion occurs after 72 hours of imbibition. The ideal conditions for evaluating seed germination of Z. sylvatica is $25{ }^{\circ} \mathrm{C}$, in paper rolls. These seeds are highly tolerant to osmotic stress, but not to salt stress. Z. sylvatica seeds can be cryopreservated without loss of germination and seed vigor.
\end{abstract}

Index terms: caatinga, lily, vigor, propagation.

\section{Caracterização da germinação de lírio-da-caatinga (Zephyranthes sylvatica (Mart.) Baker (Amarilidacea)}

\begin{abstract}
RESUMO - Zephyranthes sylvatica é um lindo lírio, endêmico da Caatinga brasileira. Embora tenha um grande potencial ornamental, pouco se sabe sobre esta espécie, especialmente em relação ao processo germinativo de suas sementes. Visando caracterizar a germinação de sementes de Z. sylvatica, estudou-se a sua curva de embebição, temperatura e substrato ótimos para a germinação e emergência das plântulas, tolerância aos estresses osmótico e salino, assim como a tolerância ao congelamento / descongelamento que indica o potencial crioarmazenamento a longo prazo. Baseado nos dados obtidos pode-se concluir que a germinação de $Z$. sylvatica apresenta modelo trifásico de embebição, em que a protrusão da raiz ocorre após 72 horas de embebição. As condições ideais para a avaliação da germinação das sementes de $Z$. sylvatica é de $25^{\circ} \mathrm{C}$, em rolos de papel. Estas sementes são altamente tolerantes ao estresse osmótico, mas não ao estresse salino. Sementes de Z. sylvatica podem ser criopreservadas sem perda de germinação e vigor das sementes.
\end{abstract}

Termos para indexação: caatinga, lírio, vigor, propagação.

\section{Introduction}

The Caatinga is the predominant biome in semi-arid climate northeastern Brazil, and it has a great diversity of plant species. These species have several potentialities that need to be studied. Among them, we can mention its ornamental potential, still unexplored. There are several trees, shrubs and herbs of great beauty in Caatinga, among these, the caatinga-lily [Zephyranthes sylvatica (Mart.) Baker (Amarilidacea)], which is an endemic species of this savanna, with a great ornamental potential due to its beautiful flowers.

${ }^{1}$ Submitted on 10/30/2013. Accepted for publication on 04/10/2014.

${ }^{2}$ Universidade do Estado da Bahia- UNEB, 48905-680 - Juazeiro, BA, Brasil.
It is an herbaceous plant which has good resistance to the natural conditions of the Caatinga, occurring in areas of sandy soil under high temperatures most of the year and irregular rainfall. This species remains leafless during most of the year, sprouting and blooming with the first rains. Its flowers are solitary and have different colors ranging from white to red (Figure 1). It is during the short rainy season that its flowers stand out in the landscape, revealing their full potential (Kiill and Santos, 2013).

Studies on seed physiological processes are an effective starting point for using and rationally exploring native species,

${ }^{3}$ Embrapa Semiárido, Caixa Postal 23, 56302-970- Petrolina, PE, Brasil. *Corresponding author < barbara.dantas@embrapa.br> 
especially in the Caatinga, where studies on germination are still scarce. Water uptake speed, optimum and cardinal temperatures, ideal substrate, abiotic stress tolerance and cryopreservation are important features of seed germination (Carvalho and Nakagawa, 2012). There is little research on this species (Felix et al., 2011; Mendes and Castro, 2010), and little is known about its germination. Thus, it is extremely important to know the factors that influence seed germination, so that they can be controlled and manipulated in order to optimize the germination process, resulting in production of more vigorous plants (Nogueira et al., 2013).Thus, given the scarcity of information, the aim of this work was to study aspects of germination of $Z$. sylvatica seeds.

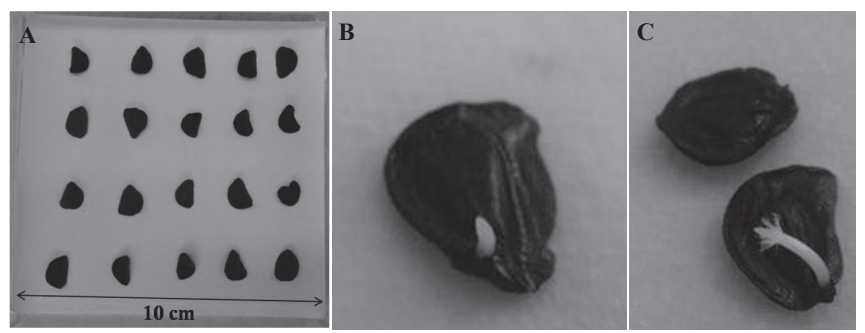

Figure 1. Zephyrantes sylvatica seeds sowed in paper towel in gerbox (A), radicle protrusion (B), seedling development (C).

\section{Material and Methods}

The seeds of Zephyranthes sylvatica were harvested from approximately 50 plants in a 0.5 ha wasteland in Petrolina, state of Pernambuco, Brazil, in January 2013, when the fruits started dehiscence. Soon after harvest, seeds were processed by the separation from the fruits and characterized for morphological features, moisture content, imbibition curve, optimum temperature, optimum substrate, salt and osmotic stress tolerance, and storage potential, as described below:

Moisture content: assessed by the oven method, at $105 \pm 3{ }^{\circ} \mathrm{C}$ during 24 hours, using two replications of 50 seeds (Brasil, 2009). The results were expressed as a percentage on a wet basis.

Imbibition curve: five samples of 20 seeds were placed to imbibe in a gerbox with two sheets of blotting paper, moistened with distilled water in an amount equivalent to 2.5 times the weight of the paper. The gerboxes were placed in a lab environment with temperature ranging from 25 to $30^{\circ} \mathrm{C}$. The seeds were weighed before and after imbibition intervals, i.e. every 1 hour until 6 hours; every 2 hours, from 6 to 12 hours, every 4 hours from 12 to 16 hours, every 8 hours from 16 to 40 hours and every 24 hours until 120 hours.
Optimum germination temperature: to characterize the optimal temperature range for germination, the seeds were placed in gerboxes with two sheets of blotting paper, moistened with distilled water in amounts equivalent to 2.5 times the weight of the paper. Seeds were subjected to 15, 20, 25, 30 and $35^{\circ} \mathrm{C}$ in Biochemical Oxygen Demand (BOD) incubators in a 12-hour photoperiod.

Optimum substrate for germination and emergence: the seeds were distributed on the substrates: paper roll (PR), on blotter paper in gerboxes (BP), in trays with individual cells, filled with sand (SS) or horticultural commercial substrate, called HS-Substrato ${ }^{\circledR}(\mathrm{CS})$. The papers were moistened with distilled water in a quantity equivalent to 2.5 times its weight. Sand and commercial substrates were moistened to $100 \%$ field capacity. All four treatments were placed in a germination chamber at $25^{\circ} \mathrm{C}$ with constant light.

Osmotic stress tolerance: in order to simulate osmotic stress, the seeds were placed in germination boxes with two sheets of blotting paper, moistened with distilled water or polyethylene glycol 6000 (PEG 6000) solutions, with the osmotic potentials of $0,-0.2,-0.4,-0.6$ and $-0.8 \mathrm{MPa}$, in volumes equivalent to 2.5 times the weight of the paper. Gerboxes were placed in Biochemical Oxygen Demand (BOD) incubators at $25^{\circ} \mathrm{C}$, with a 12-hour photoperiod.

Salt stress tolerance: in order to simulate salt stress, the seeds were germinated in gerboxes with two sheets of blotting paper, moistened with distilled water or $\mathrm{NaCl}$ solutions of $0,2,4,6$ and $8 \mathrm{dS} . \mathrm{m}^{-1}$ ), in volumes equivalent to 2.5 times the weight of the paper. Gerboxes were placed in Biochemical Oxygen Demand (BOD) incubators at $25^{\circ} \mathrm{C}$, with a 12 -hour photoperiod.

Long-term storage potential: assessed by the ability of the seeds to survive freezing temperatures. For that purpose, the seeds were packed in aluminum bags, wrapped in plastic bags and sealed properly and then stored in a freezer $\left(-20^{\circ} \mathrm{C}\right)$, an ultrafreezer $\left(-80^{\circ} \mathrm{C}\right)$, liquid nitrogen $\left(-196^{\circ} \mathrm{C}\right)$ and at room temperature $\left(25^{\circ} \mathrm{C}\right)$ for three days. After this period, the seeds were thawed and placed to germinate in germination boxes with two sheets of blotting paper, moistened with distilled water, in volume equivalent to 2.5 times the weight of the paper. Gerboxes were placed in Biochemical Oxygen Demand (BOD) incubators at $25^{\circ} \mathrm{C}$, with a 12-hour photoperiod.

Variables assessed: For temperature, substrate, osmotic stress, salt stress and storage trials, daily counts of germinated seeds were performed up to 14 days after sowing. Seeds were considered to be germinated when radicle protrusion was 2 $\mathrm{mm}$. For substrates SS and CS were considered germinated the emergence of the epicotyl, due to the difficulty of observing the root tissue. With these data, the variables assessed were germination percentage; mean germination time and mean 
germination speed (Ranal and Santana, 2006). The percentage of normal seedlings was assessed 14 days after sowing.

Experimental design and statistical analysis: a completely randomized experimental design, with four replications of 20 seeds, was used for all trials, except for imbibition curve analysis. Data were analyzed by ANOVA, using statistical software Assistat (Silva and Azevedo, 2002). The differences among the means obtained were compared by Tukey's test, at $5 \%$ probability, for substrate and storage trials. A regression analysis was performed for temperature, salt and osmotic trials.

\section{Results and Discussion}

The seeds of $Z$. sylvatica are dark brown, semicircular and occasionally kidney shaped, measuring, on average 1.72 $\mathrm{cm}$ in length, $1.3 \mathrm{~cm}$ in width and $0.52 \mathrm{~cm}^{2}$ in area (Figure 1).

Water uptake by $Z$. sylvatica seeds, which had an average $7.8 \%$ of water content, was well adjusted to the triphasic model (Figure 2) which, in optimum conditions of supply, reflect different physical and metabolic processes in each phase (Bewley et al., 2013). In phase I, or imbibition per se, water entered the Z. sylvatica seeds rapidly, showing seed coat permeability, and went on until 24 hours (Figure 2). In phase II, although major metabolic processes occured (Bewley et al., 2013), net water uptake was minimal, increasing around $40 \%$ in $Z$. sylvatica seeds in 48 hours, in comparison to a $180 \%$ of increase in the water content of quiescent seeds within 24 hours of phase I (Figure 2). At 72 hours after sowing, 18\% of the seeds showed radicle protrusion, completing germination and subsequent seedling growth, characterizing phase III (Figure 2). This triphasic pattern of germination was also observed in other seeds native of Caatinga and Cerrado, such as Poincianella pyramidalis (Tul.) L.P. Queiroz (Dantas et al., 2008a) and Schinopsis brasiliensis Engel. (Dantas et al., 2008b).

Temperature strongly influences the germination process, especially water absorption and chemical reactions that will mobilize or degrade stored reserves and synthesis of several important molecules for seedling growth (Bewley et al., 2013). Usually, seeds germinate under optimal temperature range that varies depending on the species. The optimum temperature is the one whereby germination process is carried out quickly, and the maximum and minimum temperatures are thresholds, and no germination occurs above or below them (Carvalho and Nakagawa, 2012). Thus, biological and ecological information is provided when we observe that the seeds of different species have varying behaviors for temperature (Bewley et al., 2013). The temperature of $25^{\circ} \mathrm{C}$ was the most suitable for the germination of $Z$. sylvatica, which presented higher germination and percentage of normal seedlings. The influence of temperature on seed germination can be determined not only by the germination and normal seedling of species, but also by other kinetic variables at each incubation temperature (Carvalho and Nakagawa, 2012). In the present study, the greatest average germination speed and the lowest average germination time were both obtained at $25^{\circ} \mathrm{C}$.

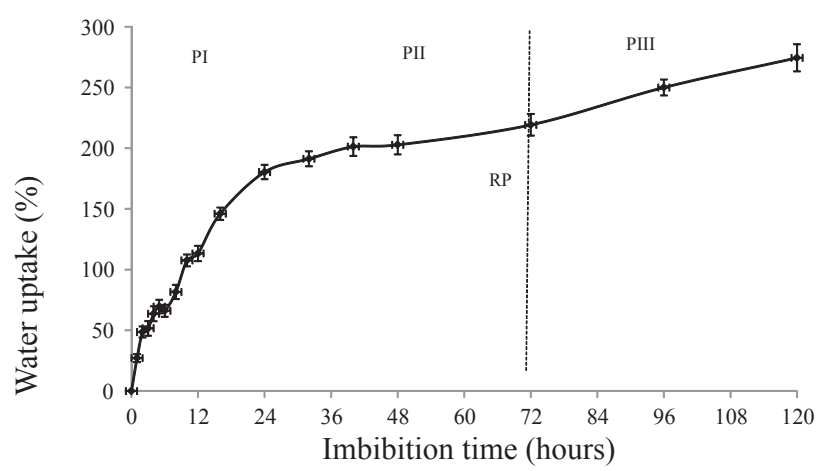

Figure 2. Imbibition curve of Z. sylvatica seeds, increase in fresh weight compared with initial quiescent seed weight due to water uptake. $\mathrm{PI}=$ phase I; PII= phase II; PIII= phase III; $\mathrm{RP}=$ radicle protrusion. The points represent the means \pm standard errors.

There was no germination at $35^{\circ} \mathrm{C}$, but this temperature did not cause death of the seeds. After 14 days of evaluation, one half of the non-germinated seeds at $35{ }^{\circ} \mathrm{C}$ were soaked in $0.1 \%$ tetrazolium solution, which revealed that the seeds were alive. The remaining seeds were germinated in sand at $25^{\circ} \mathrm{C}$, and it was observed a high percentage of seedling emergence (visual observation). Thus, it is believed that the seeds of $Z$. sylvatica subjected to $35{ }^{\circ} \mathrm{C}$ showed thermodormancy. In addition, very high temperatures may damage the germination of some species, causing denaturation of proteins that are essential for the germination process (Dousseau et al., 2008). On the other hand, lower temperatures, in general, extend the period of germination, as a result of reduction in the activity of enzymes involved in metabolism, as well as reduction in respiration (Bewley et al., 2013). At $15{ }^{\circ} \mathrm{C}$, there were no normal seedlings in spite of the $30 \%$ radicle protrusion at this temperature (Figure 3). Once $25{ }^{\circ} \mathrm{C}$ was discovered to be the best temperature for Z. sylvatica seeds (Figure 3), all subsequent trails were performed at $25^{\circ} \mathrm{C}$.

The substrate is important for the germinating seeds, with the function to provide the optimum conditions for seed germination. Factors such as aeration, water retention capacity and structure can influence the germination and development of seedlings (Barbosa et al., 1990). Thus, the choice of the substrate to be used should take into account seed size, its 
requirement on the amount of water, light sensitivity and ease that it provides for the development and evaluation of seedlings (Brasil, 2009). In addition, excess or lack of water in the substrate can be detrimental to germination by interfering with the results of germination and vigor tests (Oliveira, 2007). The paper substrates were more efective in evaluating germination due to the fast and more stable results (Figure 4). Although values of radicle protrusion cannot be compared to seedling emergence, the results obtained with seeds germinated in paper substrate (radicle protrusion) showed lower standard errors (Figure 4A) and should be preferable to evaluate seed quality. Furthermore, the higher percentage of normal seedlings was obtained from paper substrates (Figure 3B).
Among all substrates, paper rolls produced higher germination and percentage of normal seedlings (Figures 4 A, B), as well as lower germination time and higher germination speed, showing faster germination (Figures 4C, D), in comparison to the other substrates. Seeds of many species native of the caatinga can also be better evaluated in paper substrates. For instance, germination and seed vigor evaluation of Myracrodruon urundeuva Fr. All., in paper substrates at 25 and $27^{\circ} \mathrm{C}$ showed satisfactory results (Pacheco et al., 2006) on the germination of Mimosa caesalpiniaefolia Benth. The paper substrate was more appropriate to evaluate the physiological quality, regardless of temperature, compared to the sand and vermiculite substrates (Alves et al., 2002).
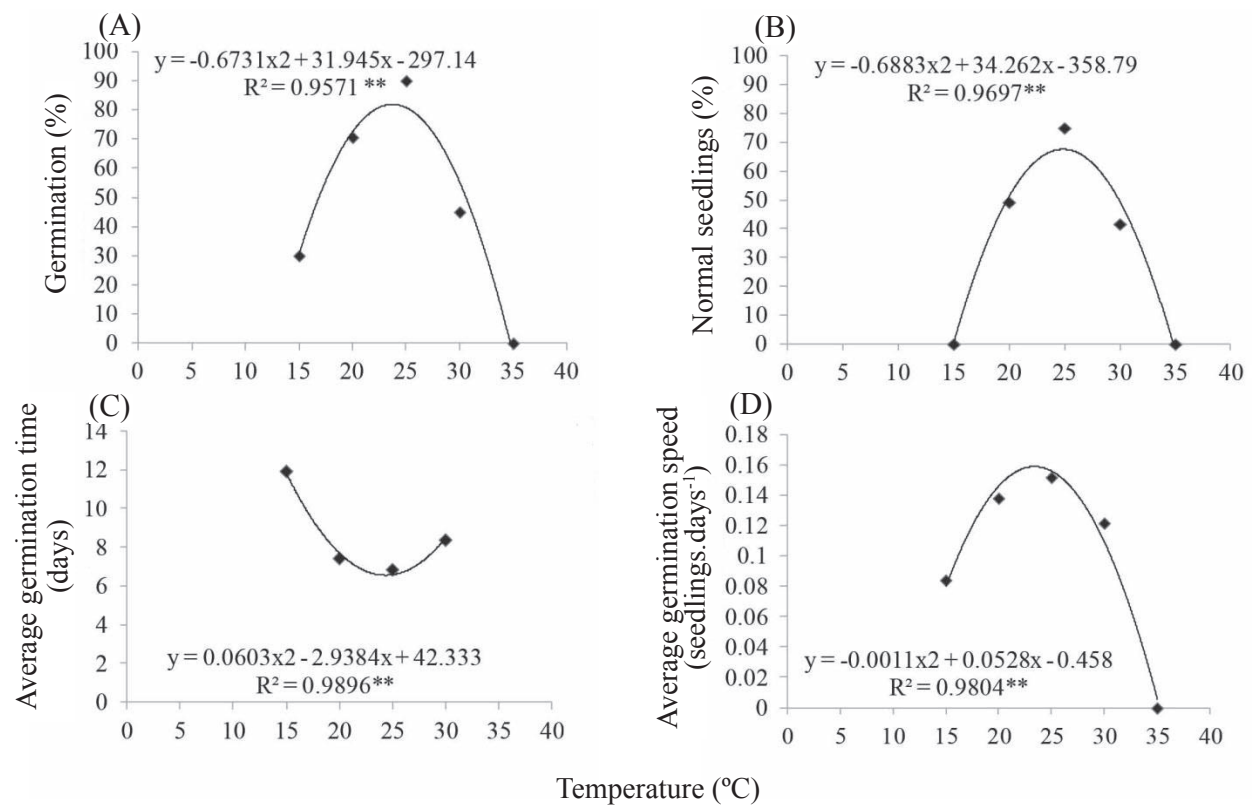

Figure 3. Germination (A), normal seedlings (B), average germination time (C), average germination speed (D) of Z. sylvatica seeds at different temperatures.

** value significant at $1 \%$.

Studies on seed germination in artificial stress conditions are particularly important for physiological ecology, providing an assessment of the limits of tolerance and adaptation of species to natural stress conditions (Guedes et al., 2013). Z. sylvatica seeds seem to be tolerant to osmotic stress, showing the best results when germinated in $-0.4 \mathrm{MPa}$, with values around $90 \%$ germination and normal seedlings and $70 \%$ in distilled water (Figures $5 \mathrm{~A}, \mathrm{~B}$ ). The germination kinetics showed unexpected results. Seeds germinated in $-0,8 \mathrm{MPa}$ had much higher average germination speed than those germinated in distilled water, reducing the average germination time in more than three days (Figures 5C, D). Water stress can affect germination, causing delay in the initiation or decrease in the final stand. Therefore, the ability of the seeds of some species to germinate under water stress conditions give them ecological advantages over others that are susceptible to drought (Rosa et al., 2005).

Drought is a frequent phenomenon and typical of northeastern Brazil, with variable intensity and effects in space and time. It is triggered by persistent lack of significant rainfall, where the spatial and temporal variability of precipitation makes the occurrence of this phenomenon more frequent (Reis et al., 2012). As a result, many Caatinga native or well adapted species are tolerant to osmotic stress, such as the trees Apeiba tibourbou Aubl (Guedes et al., 2013), Erythrina velutina (Reis et al., 2012), Mimosa caesalpiniifolia (Moura et al., 2011) and Myracrodruon urundeuva (Virgens et al., 2012); the shrubs Cajanus cajan (Marin et al., 2004), 
Gossypium hirsutum var. latifolium (Meneses et al., 2011) and the herb Tripogon spicatus (Fernandes Junior et al., 2012). Although these species are acknowledged to be tolerant to drought their seeds showed little or no germination at $-0,8 \mathrm{MPa}$ and none of them showed $80 \%$ germination at this osmotic potential.
(A)
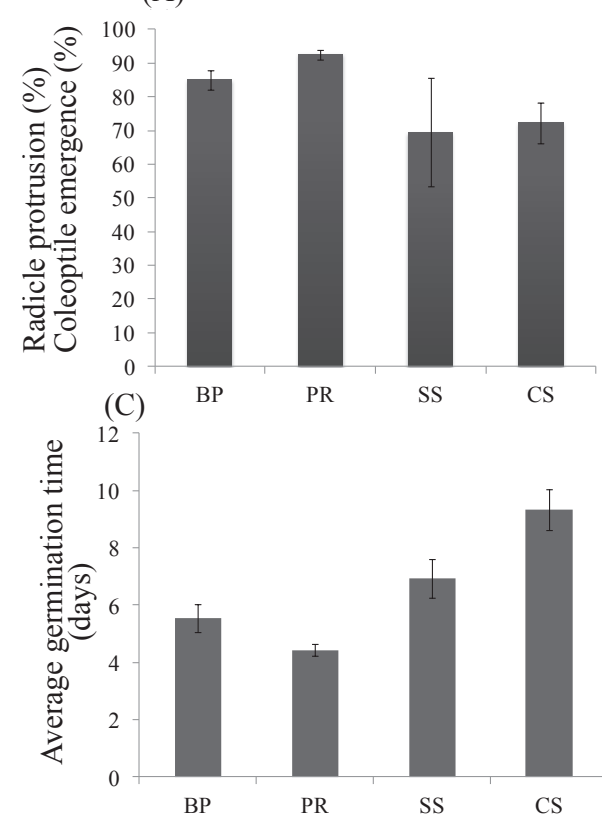

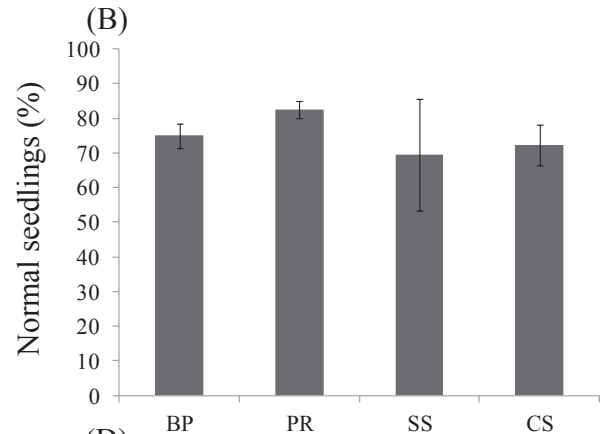

(D)

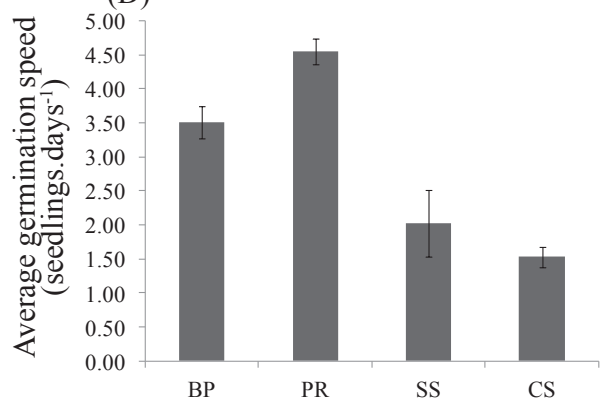

Substrates

Figure 4. Radicle protrusion (germination for BP, PR), emergence (for SS, CS) (A), normal seedlings (B), average germination time (C), average germination speed (D) of $Z$. sylvatica seeds in different substrates, at $25^{\circ} \mathrm{C}$. $\mathrm{BP}=$ blotter test paper; $\mathrm{PR}=$ paper rolls; $\mathrm{SS}=$ sand; $\mathrm{CS}=$ commercial substrate.

** value significant at $1 \%$. The columns represent means \pm standard errors.

(A)

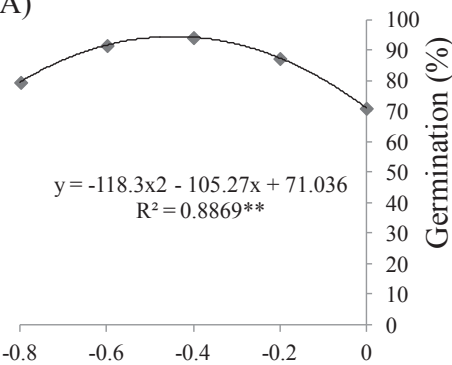

(C)

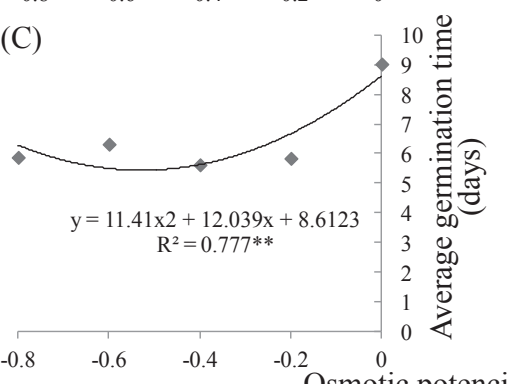

(B)

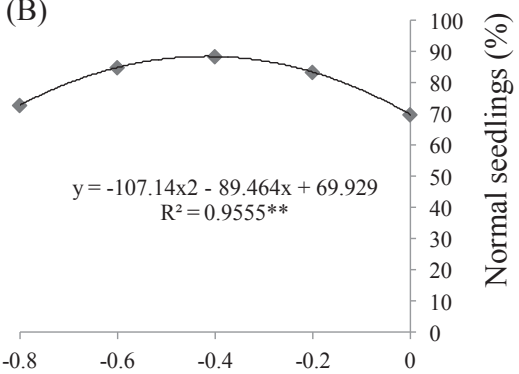

(D)

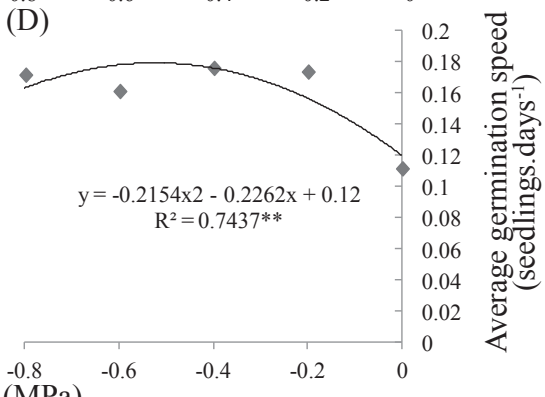

Figure 5. Germination (A), normal seedlings (B), average germination time (C), average germination speed (D) of Z. sylvatica seeds at osmotic potentials.

** value significant at $1 \%$. 
In addition to the low availability of water, soils of arid regions often have a high level of salinity. Salts of high solubility are the most harmful, because the seeds uptake salts during imbibition. When excessive, they cause toxicity and cause physiological disorders to seeds, reducing their germination potential (Ferreira, 1997; Bansal et al., 1980). When the seeds were subjected to salt solutions with different electrical conductivity, the increasing salinity decreased germination and

(A)
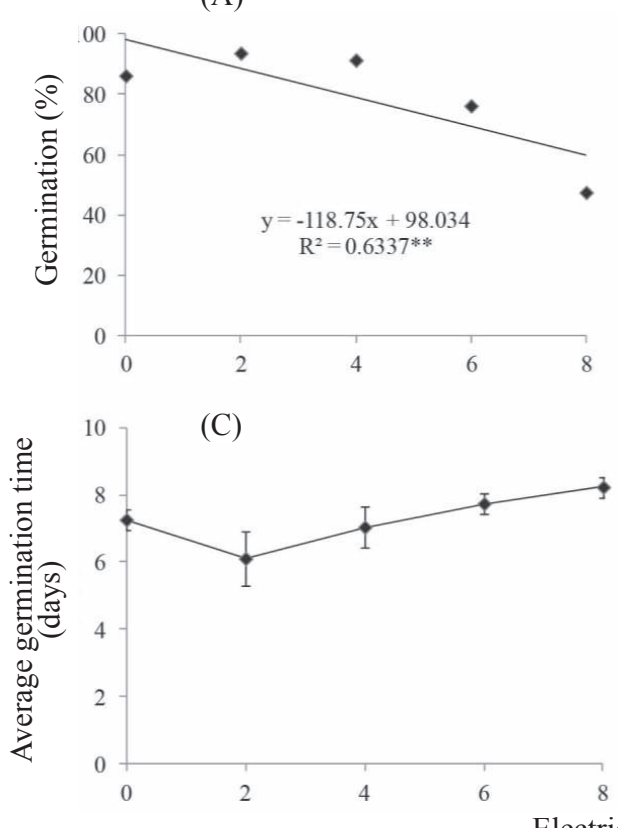

percentages of normal seedlings, which fell from over $90 \%$ to $40 \%$ and $20 \%$, respectively (Figures $6 \mathrm{~A}, \mathrm{~B}$ ). On the other hand, germination kinetics was not influenced by increasing salinity between treatments (Figure $6 \mathrm{C}, \mathrm{D}$ ). The reduction of germination, as compared with the control, is indicative of the level of salinity tolerance of the species. In this method, the ability to germinate also indicates plant tolerance to salts in subsequent stages of development (Góis et al., 2008).
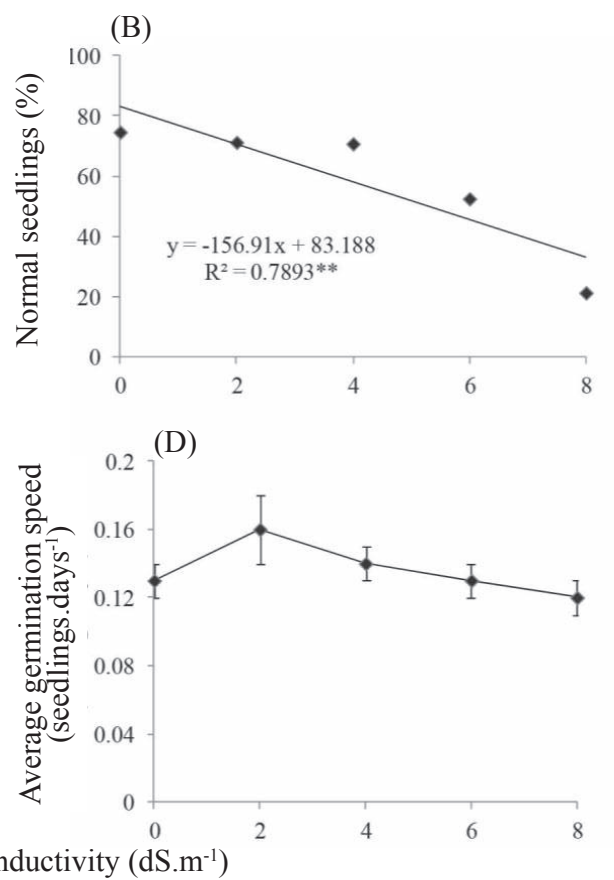

Figure 6. Germination (A), normal seedlings (B), average germination time (C), average germination speed (D) of Z. sylvatica seeds at different electrical conductivities.

** value significant at $1 \%$. The points represent the means \pm standard errors.

Although seeds of various species from Caatinga are highly tolerant to salt stress (Dantas and Ramos, 2012), seeds of $Z$. sylvatica have a low tolerance threshold to salt stress and can be considered a glycophyte with moderate tolerance to $\mathrm{NaCl}$. The reduction in germination percentage with increasing salinity stress for Z. sylvatica seeds (Figure 6) may be associated with toxic levels of ion concentration within seeds (Tobe et al., 2000), since the osmotic potential of a $8 \mathrm{dS} . \mathrm{m}^{-1} \mathrm{NaCl}$ solution at $25^{\circ} \mathrm{C}$ is $-0.32 \mathrm{MPa}$ (Souza et al., 2010), which did not affect seed germination for this species (Figure 5).

The conservation of seeds has the basic function of preserving their physiological quality. This preservation is possible, because proper storage reduces the speed of deterioration, which is an irreversible process (Delouche et al., 1973). Z. sylvatica seeds showed no significant difference among cryopreservation conditions for germination percentage and kinetics, as well as for percentage of normal seedlings (Table 1), showing that these orthodox seeds are highly tolerant to the frosting and eventual defrosting of ultralow temperature storage. The slow thawing at room temperature, which was conducted in this study, may have influenced preservation of the physiological quality of $Z$. sylvatica seeds. Thus, the use of ultralow temperatures becomes an alternative in the preservation of seeds by reducing their metabolic process and minimizes or even stops the deterioration process, enabling seed storage indefinitely without changes in structure and vigor (Santos, 2001). It is worth noting that the seeds subjected to cryogenic temperatures cease their metabolic activity, preventing loss of energy and remaining at latent state. In this situation, physical and biochemical structures of seeds are preserved and high physiological quality is maintained (Goldfarb et al., 2010). 
Table 1. Germination (G), normal seedlings (NS), average germination time (AGT), average germination speed (AGS) of $Z$. sylvatica seeds at different three-day storage temperatures.

\begin{tabular}{ccccc}
\hline $\begin{array}{c}\text { Storage temperature } \\
\left({ }^{\circ} \mathrm{C}\right)\end{array}$ & $\begin{array}{c}\mathrm{G} \\
(\%)\end{array}$ & $\begin{array}{c}\text { NS } \\
(\%)\end{array}$ & $\begin{array}{c}\text { AGT } \\
(\text { days })\end{array}$ & $\begin{array}{c}\text { AGS } \\
\text { (seedlings.day }^{-1} \text { ) }\end{array}$ \\
\hline 25 & $86.25 \mathrm{a}^{*}$ & $7.75 \mathrm{~b}$ & $7.26 \mathrm{a}$ & $0.13 \mathrm{a}$ \\
-20 & $96.25 \mathrm{a}$ & $16.25 \mathrm{a}$ & $6.82 \mathrm{a}$ & $0.14 \mathrm{a}$ \\
-80 & $87.50 \mathrm{a}$ & $14.00 \mathrm{ab}$ & $7.37 \mathrm{a}$ & $0.14 \mathrm{a}$ \\
-196 & $88.75 \mathrm{a}$ & $14.00 \mathrm{ab}$ & $8.11 \mathrm{a}$ & $0.12 \mathrm{a}$ \\
\hline $\mathrm{CV}(\%)$ & 11.52 & 23.02 & 15.42 & 16.35 \\
\hline
\end{tabular}

*Means followed by same letter in columns do not differ according to Tukey test at $5 \%$.

\section{Conclusions}

The germination of $Z$. sylvatica shows triphasic model of imbibition, in which the primary root protrusion occurs after 72 hours of imbibition.

The ideal conditions for evaluating germination of $Z$. sylvatica seeds is $25^{\circ} \mathrm{C}$, in paper rolls.

Z. sylvatica seeds are highly tolerant to osmotic stress, but not to salt stress.

Z. sylvatica seeds can be cryopreservated without loss of germination and seed vigor.

\section{References}

ALVES, E.U.; PAULA, R.C.; OLIVEIRA, A.P.; BRUNO, R.L.A.; DINIZ, A.A. Germinação de sementes de Mimosa caesalpinifolia Benth. em diferentes substratos e temperaturas. Revista Brasileira de Sementes, v.24, n.1, p.169-178, 2002. http://dx.doi.org/10.1590/S0101-31222002000100025

BANSAL, R.P.; BHATI, P.R.; SEN, D.N. Differential specificity in water inhibition of Indian arid zone. Biologia Plantarum, v.22, n.5, p.327-331, 1980. http://link.springer.com/article /10.1007/BF02908976

BARBOSA, J.M.; BARBOSA, L.M.; SILVA, T.S.; FERREIRA, D.T.L. Influência de substrato e temperaturas na germinação de sementes de duas frutíferas silvestres. Revista Brasileira de Sementes, v.12, n.2, p.66-73, 1990. http://www.abrates.org.br/revista/artigos/1990/v12n2/ artigo07.pdf

BEWLEY, J.D.; BRADFORD, K.J; HILHORST, K.H.W.M; NONOGAKI, H. Seeds: physiology of development germination and dormancy. New York: Springer, 2013. 392p.

BRASIL. Ministério da Agricultura, Pecuária e Abastecimento. Regras para análise de sementes. Ministério da Agricultura, Pecuária e Abastecimento. Secretaria de Defesa Agropecuária. Brasília: MAPA/ACS, 2009. 395p. http:// www.bs.cca.ufsc.br/publicacoes/regras\%20analise \%20sementes.pdf

CARVALHO, N.M.; NAKAGAWA, J. Sementes: ciência, tecnologia e produção. 4.ed. Jaboticabal-SP: UNESP, 2012. 590p.

DANTAS, B.F.; RAMOS, D.L.D. Germinação de sementes da Caatinga em água biossalina. Informativo Abrates, v.22, n.3, p.32-35, 2012. http://www. abrates.org.br/portal/images/Informativo/v22 n3/Palestras_compactado.pdf
DANTAS, B.F.; CORREIA, J.S.; MARINHO, L.B.; ARAGÃO, C.A. Alterações bioquímicas durante a embebição de sementes de catingueira (Caesalpinia pyramidalis Tul.). Revista Brasileira de Sementes, v.30, n.1, p.221-227, 2008a. http://dx.doi.org/10.1590/S0101-31222008000100028

DANTAS, B.F.; SOARES, F.S.J.; LÚCIO, A.A.; ARAGÃO, C.A. Alterações bioquímicas durante a embebição de sementes de baraúna (Schinopsis brasiliensis Engl.). Revista Brasileira de Sementes, v.30, n.2, p.214-219, 2008b. http://dx.doi.org/10.1590/S0101-31222008000200027

DELOUCHE, J.C.; MATTHES, R.K.; DOUGHERTY, G.M.; BOYD, A.H. Storage of seed in sub-tropical and tropical regions. Seed Science and Technology, v.1, n.3, p.671-700, 1973.

DOUSSEAU, S.; ALVARENGA, A.A.; ARANTES, L.O.; OLIVEIRA, D.M.; NERY, F.C. Germinação de sementes de tanchagem (Plantago tomentosa Lam.): influência da temperatura, luz e substrato. Ciência e Agrotecnologia, v.32, n.2, p.438-443, 2008. http://www.scielo.br/pdf/cagro/v32n2/14.pdf

FELIX, W.J.P.; FELIX, L.P.; MELO, N.F.; OLIVEIRA, M.B.M.; DUTILH, J.H.A.; CARVALHO, R. Karyotype variability in species of the genus Zephyranthes Herb. (Amaryllidaceae- Hippeastreae). Plant Systematics and Evolution, v.294, p.263-271, 2011. <http://link.springer.com/ article/10.1007\%2Fs00606-011-0467-6\#page-2>

FERNANDES JUNIOR, P.I.; AIDAR, S.T.; GAVA, C.A.T.; ZILLI, J.E.; MARTINS, L.M.V. Caracterização fenotípica de bactérias diazotróficas associadas a Tripogon spicatus no Bioma Caatinga. Petrolina: Embrapa Semiárido, 2012. 19 p. (Boletim de Pesquisa e Desenvolvimento, 98). http:// www.infoteca.cnptia.embrapa.br/handle/doc/943120

FERREIRA, P.A. Aspectos físico-químicos do solo. In: GHEYI, H.R.; QUEIROZ, J.E. \& MEDEIROS, J.F. Manejo e controle da salinidade na agricultura irrigada. Campina Grande: UFPB/SBEA, 1997. p.37-67.

GÓIS, V.A.; TORRES, S.B.; PEREIRA, R.A. Germinação de sementes de maxixe submetidas a estresse salino. Revista Caatinga, v.21, n.4, p.64-67, 2008. http://caatinga.ufersa.edu.br /index.php/sistema/article/ viewFile/798/412

GOLDFARB, M.; DUARTE, M.E.M.; MATA, M.E.R.M.C. Armazenamento criogênico de sementes de pinhão manso (Jatropha curcas L.) Euphorbiaceae. Biotemas, v.23, n.1, p.27-33, 2010. https://periodicos.ufsc.br/index.php/ biotemas/article/view/2175-7925.2010v23n1p27

GUEDES, R.S.; ALVES, E.U.; VIANA, J.S.; GONÇALVES, E.P.; LIMA, C.R.; SANTOS, S.R.N. Germinação e vigor de sementes de Apeiba tibourbou submetidas ao estresse hídrico e diferentes temperaturas. Ciência Florestal, v.23, n.1, p.45-53, 2013. http://cascavel.ufsm.br/revistas/ojs-2.2.2/index.php/ cienciaflorestal/article/view/8438/pdf 
KIILL, L.H.P.; SANTOS, A.P.B. Lirio-da-Caatinga (Zephyranthes sylvatica). Petrolina: Embrapa Semiárido, 2013. N.1, Folder.

MARIN, A.; SANTOS, D.M.M.; BANZATTO, D.A.; FERRAUDO, A.S. Geminação de sementes de guandu sob efeito de disponibilidade hídrica e de doses sub-letais de alumínio. Bragantia, v.63, n.1, p.13-24, 2004. http:// dx.doi.org/10.1590/S0006-87052004000100002

MENDES, M.R.A.; CASTRO, A.A.J.F. Vascular flora of semi-arid region, São José do Piauí, state of Piauí, Brazil. Check List, v.6, n.1, p.39, 2010. http://www.checklist.org.br /getpdf?SL055-09

MENESES, C.H.S.G.; BRUNO, R.L.A.; FERNANDES, P.D.; PEREIRA, W.E.; LIMA, L.H.G.M.; LIMA, M.M.A.; VIDAL, M.S. Germination of cotton cultivars seeds under water stress induced by polyethyleneglycol-6000. Scientia Agricola, v.68, n.2, p.131-138, 2011. http://dx.doi.org/10.1590/ S0103-90162011000200001

MOURA, M.R.; LIMA, R.P.; FARIAS, S.G.G.; ALVES, A.R.; SILVA, R.B. Efeito do estresse hídrico e do cloreto de sódio na germinação de Mimosa caesalpiniifolia Benth. Revista Verde, v.6, n.2, p.230 - 235, 2011. http://www. gvaa.com.br/revista/index.php/RVADS/article/viewFile/830/pdf_255

NOGUEIRA, N.W.; RIBEIRO, M.C.C.; FREITAS, R.M.O.; GURGEL, G.B; NASCIMENTO, L.N. Diferentes temperaturas e substratos para germinação de sementes de Mimosa caesalpiniifolia Benth. Revista de Ciências Agrarias, v.56, n.2, p.95-98, 2013. http://dx.doi.org/10.4322/rca. 2013.015

OLIVEIRA, O. S. Tecnologia de sementes florestais. Curitiba: Imprensa Universitária, 2007. 185p.

PACHECO, M.V.; MATOS, V.P.; FERREIRA, R.L.C.; FELICIANO, A.L.P.; PINTO, K.M.S. Efeito de temperaturas e substratos na germinação de sementes de Myracrodruon urundeuva Fr. All.(Anacardiaceae). Revista Árvore, v.30, n.3, p. 359-367, 2006. http://dx.doi.org/10.1590/S010067622006000300006

REIS, R.C.R.; DANTAS, B.F.; PELACANI, C.R. Mobilization of reserves and germination of seeds of Erythrina velutina Willd. (Leguminosae Papilionoideae) under different osmotic potentials. Revista Brasileira de Sementes, v.34, n.4, p.580-588, 2012. http://www.alice.cnptia. embrapa.br/ handle/doc/950565
ROSA, L.S.; FELIPPI, M.; NOGUEIRA, A.C.; GROSSI, F. Avaliação da germinação sob diferentes potenciais osmóticos e caracterização morfológica da semente e plântula de Ateleia glazioviana BAILL (TIMBÓ). Cerne, v.11, n.3, p.306-314, 2005. http://www.redalyc.org /articulo.oa?id=74411309

RANAL, M.A.; SANTANA, D.G.D. How and why to measure the germination process? Revista Brasileira de Botânica, v.29, n.1, p.1-11, 2006. http://dx.doi.org/10.1590/S0100840420060 00100002

SANTOS, I.R.I. Criopreservacao de germoplasma vegetal: a alternativa para a conservação a longo prazo. Biotecnologia Ciencia \& Desenvolvimento, v.4, n.20, p.60-65, 2001. http://www.biotecnologia.com.br/revista/bio20/20_13.pdf

SILVA, F.A.S.; AZEVEDO, C.A.V. Versão do programa computacional Assistat para o sistema operacional Windows. Revista Brasileira de Produtos Agroindustriais, v.4, n.1, p.71-78, 2002. http://dx.doi.org/10.1590/S000687052004000100002

SOUZA, Y.A.; PEREIRA, A.L.; SILVA, F.F. S.; REIS, R.C.R.; EVANGELISTA, M.R.V.; CASTRO, R.D.; DANTAS, B.F. Efeito da salinidade na germinação de sementes e no crescimento inicial de mudas de pinhão-manso. Revista Brasileira de Sementes, v.32, n.2, p.83-92, 2010. http://dx.doi.org/10.1590/ S0101-31222010000200010

TOBE, K.; LI, X.; OMASA, K. Seed germination and radicle growth of a halophyte, Kalidium capsicum (Chenopodiaceae).Annals of Botany, v.85, p.391396, 2000. <http://aob.oxfordjournals.org/content/85/3/391.full.pdf + html >

VIRGENS, I.O.; CASTRO, R.D; FERNANDEZ, L.G.; PELACANI, C.R. Comportamento fisiológico de sementes de Myracrodruon urundeuva Fr. All. (Anacardiaceae) submetidas a fatores abióticos. Ciência Florestal, v.22, n.4, p.681-692, 2012. http://www.redalyc.org/articulo.oa?id=53424836003 